\title{
A Study on the Impact of International Labor Standards on China 's Textile and Apparel Export
}

\author{
Chunxiao Hou \\ 16120545@bjtu.edu.cn \\ School of Economics and Management, Beijing Jiaotong University, Beijing, China \\ ${ }^{*}$ Corresponding author
}

\begin{abstract}
Keywords: International Labor Standards, Export of Textiles and Garments, Labor-intensive Industries
\end{abstract}

\begin{abstract}
As the traditional labor-intensive industry in our country, the textile industry plays a supportive role in the economy of our country. Recently, the RMB exchange rate has retreated. The textile and garment industry is expected to usher in an inflection point. Its quota has drawn wide attention. At the same time, the international labor standards have drawn increasing attention from its birth to its development all over the world. Some countries have included relevant labor standards in their free trade agreements, either for the protection of the domestic textile and clothing industry or for their emphasis on human rights provisions. Based on the data from 2001 to 2015, we use the sequence autoregressive model, the BG test and the Ramsey RESET Test to examine the influence of the labor standards on the textile exports in China. In the end, we draw conclusions.
\end{abstract}

\section{Introduction}

In China's export trade, the textile and apparel industry has a long history. Against the backdrop of increasingly globalized economy, the huge international market has enabled the export trade of China's textile and apparel industry to an unprecedented level. Meanwhile, the prevalence of international trade protectionism has also restricted the development of China's textile and clothing industry. Major economies such as the United States and Europe have always used the exception mechanism in free trade agreements to introduce labor provisions in free trade to eliminate the comparative advantages and international competitiveness of the trading-competitive countries. Even though international labor standards are not formally incorporated into the WTO framework, this does not prevent them from being integrated into international trade in varying degrees. Under the favorable conditions of the RMB exchange rate correction, the relationship between China's textile and garment export trade and international labor standards is particularly worthy of our consideration. It is better for us to meet the trade agreements which are based on labor standards in the future and seize this rare inflection point to increase the industry's exports.

Since the last century, the impact of international labor standards on the export of a country's products has been widely concerned by scholars. In order to measure labor standards indicators, different scholars use different indicators to quantify, which include monetary wages, wage rates of change and average wage levels. At the same time, many scholars also study the relationship between labor standards and export trade. And they put forward different conclusions on the research on the relationship between this two variables. Chen Hong (2009), Zhang Jinfei (2014) and Li Jiachun (2010) think that trade exports and labor standards have a negative correlation. Aggarwal (1995), Xu Songtao (2008) put forward different conclusions.

To sum up, we can see that different scholars choose different variables to study the impact of international labor standards on China's export industry, and thus get different opinions. In recent years, the research literature is relatively small. At the same time, as the United States and European Union actively carry out new regional trade, labor standards will surely occupy an important position in future trade agreements. Therefore, in today's trading environment, we still need to go deeper to understand this topic. 


\section{Organization of the text}

In the third part of the article, we analyze the international labor standards that our garment export markets face. In the fourth part of the article, we construct the corresponding model and do an empirical analysis on the impact of international labor standards on the export of textile industry. This part includes the selection of variables, the construction of models and the regression test. In the fifth part of the article, we analyze the empirical results and draw the corresponding conclusions.

\section{China's textile and garment industry is facing labor standards}

Anti-dumping has always been a "nightmare" for China's export products, while textiles and clothing products account for $11.3 \%$ of the total weight in these cases. As a labor-intensive industry, exports of textiles and clothing are vulnerable to international labor standards.

First of all, from a legal point of view, the corresponding domestic labor legislation has a considerable gap compared with that of the rest of the world. From the wage point of view, despite providing a large number of jobs, the salaries provided by the textile and garment industry are hovering at low levels. In terms of working environment, some private enterprises provide poor working conditions and even some unhealthy and unsafe environmental factors such as dim lighting and dyes with excessive levels of toxic substances. At the same time, there are cases in which employees work overtime in order to increase the amount of products.

From the point of view of social security, many foreign importers pay attention to whether the exporter has assumed the social responsibility of protecting employees. However, the basic situation of social security for serving staff in our country is not good: the data in the figure below only shows the trend in 2014, but the coverage rate of the three basic risks such as unemployment, work injury and medical treatment are not high in our country. It is estimated at more than 16 percentage points in 2016, which is far below that of developed countries. As part of employee benefits, social insurance is also used as a factor in judging the labor standards of enterprises. Therefore, some importers do not accept products exported by enterprises with low employee insurance coverage.

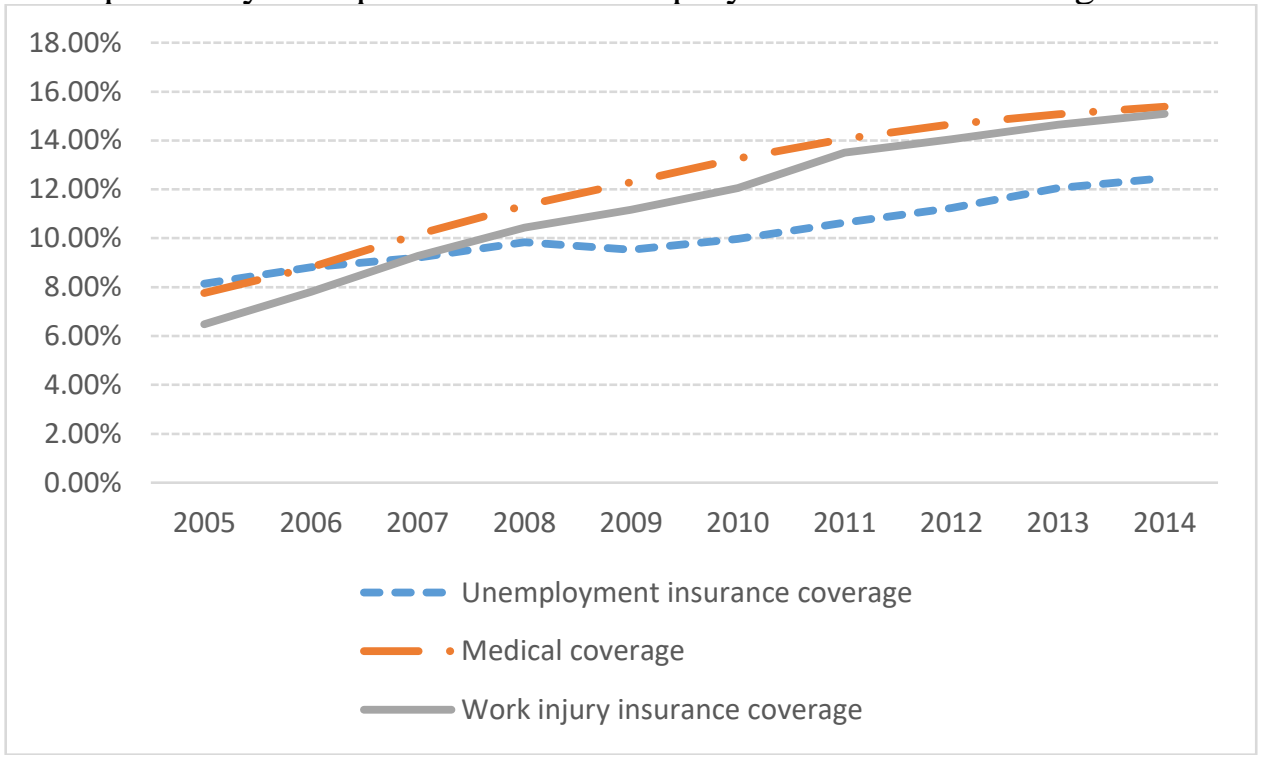

Fig.1 Coverage of three types of employees in service

\section{Empirical Analysis}

\section{1 variable selection}

This paper selects the proportion of China's textile and apparel exports to total exports of goods from 2001 to 2015 to represent the basic development of this industry. Then, this paper selects the wage level of this very intuitive indicator as an independent variable to represent our labor standard status. 


\section{2 model setting and regression test results}

From the figure we can see that with the increase of $x$, the value of $y$ has a simple tendency to decrease. At the same time, it can be found that the graph can be divided into three sections as shown in the following figure:

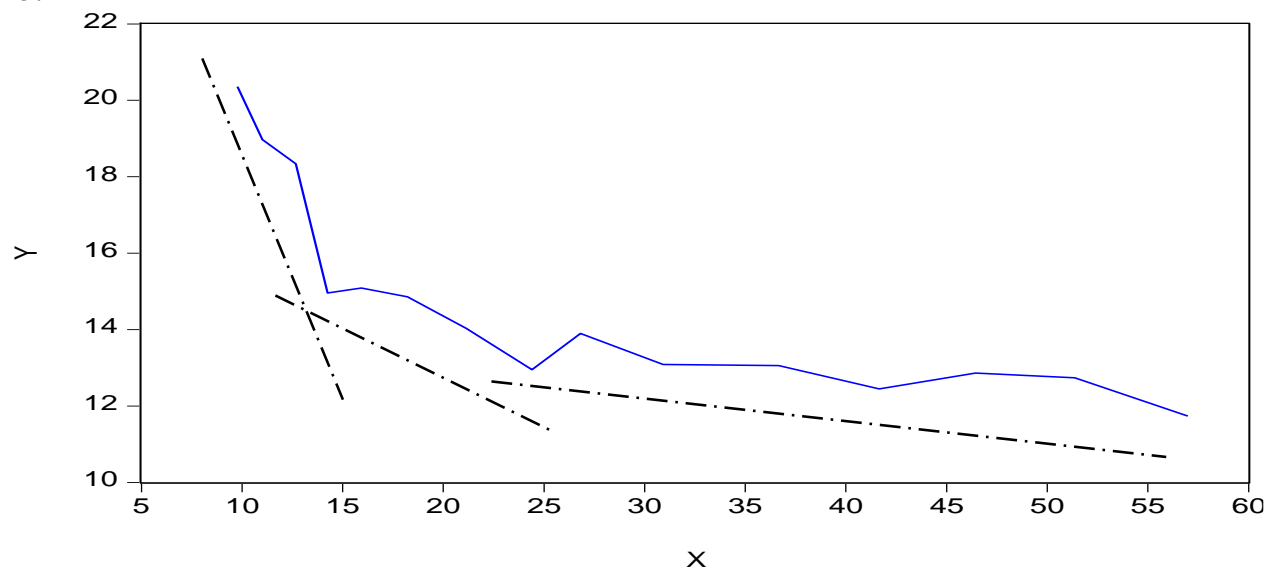

Fig.2 Segmented line chart of variable XY

The reasons for the fragmentation were analyzed as follows. Firstly, the elimination of quotas for textiles in 2005 leads to fair competition opportunities in our sector and a larger international market. This situation alleviates the negative impact of rising labor standards on the export of wages to textile and apparel. Second, it is because the 2008 global financial crisis. However, as a traditional enterprise, the textile and apparel industry has a strong foundation to make its affected fluctuations relatively small.

In order to better simulate the relationship between arguments and dependent variables, I will introduce $\mathrm{d} 1, \mathrm{~d} 2$ as a new dummy variable to better build the model. When d 1 equals 0 , it means that before the quota of textile products is canceled in 2005, and 1 means the quota is canceled. When $\mathrm{d} 2$ equals to 0 , it means that it is before the 2008 financial crisis, 1 means after the financial crisis.

So we initially set the model as:

$$
Y=C+\beta_{1} X+\beta_{2} d_{1}+\beta_{3} d_{2}
$$

\section{3 model modification and testing}

This paper first conducted the least square test, the result is not very satisfactory, especially the variable $\mathrm{d} 2$. Therefore, this article delete this variable and introduce cross-variables:

$$
Y=C+\beta_{1} X+\beta_{2} d_{1}+\beta_{3} X d_{1}
$$

\begin{tabular}{c|ccccc}
\multicolumn{7}{c}{ Table 1 OLS Results } \\
\hline & $\mathrm{C}$ & $\mathrm{X}$ & $\mathrm{D} 1$ & $\mathrm{X} * \mathrm{D} 1$ & R-squared \\
\hline Coefficient & 31.50 & -1.11 & -16.00 & 1.58 & 0.96 \\
Prob. & 0.00 & 0.00 & 0.00 & 0.00 & \\
\hline
\end{tabular}

From Table 1, we can see that the probabilities of X, D1, XD1 are 0.0001, 0, 0.0001. They are less than 0.05 , which means that the regression parameters are more significant. The p-value of the companion probability of F-statistic is 0 , which means the equation is significant. R-squared is 0.958927 , which means the equation is a good fit. DW value of 2.4308 shows that the autocorrelation is not very obvious. Ramsey RESET Test results are as follows:

Table 2 Ramsey RESET Test Results

\begin{tabular}{c|ccc}
\hline & Value & df & Probability \\
\hline t-statistic & 0.966614 & 10 & 0.3565 \\
F-statistic & 0.934342 & $(1,10)$ & 0.3565 \\
Likelihood ratio & 1.339851 & 1 & 0.2471 \\
\hline
\end{tabular}

Prob (t) and Prob (F) are 0.3565 , and the probability of rejecting the null hypothesis is 0.3565 , then the null hypothesis can not be rejected. Therefore, the model is set to meet the requirements and 
the variables can explain the changes of the independent variables.

White test results show that Prob (F) and Prob (Obs * R2) values of 0.5181 and 0.4138 are greater than 0.05 indicates that the model does not have significant heteroskedasticity.

\section{Conclusion}

According to the above analysis we can get the regression results:

$$
\mathrm{Y}=31.5050-1.1190 \mathrm{X}-16.0005 \mathrm{~d} 1+1.0548 \mathrm{X} * \mathrm{~d} 1
$$

After textile quotas were removed, the model was simplified to:

$$
\mathrm{Y}=15.5045-0.0642 \mathrm{X}
$$

Compared with the formula of (4), the whole line is much smoother. Compared with the same value of wage change before 2005, the effect on the current export of textile and garment industry is relatively small. The wage for every increase of 1000 yuan, the proportion of the industry's exports will be reduced by 0.0642 percentage points. The reason can be divided into the following points:

First of all, after the abolition of textile quotas, China has a larger international sales market and fair competition opportunities. To a certain extent, the larger demand on the international market has offset the negative impact brought by the increase labor wages. Therefore the labor standards can weaken the negative impact of labor standards on the export of textile and apparel.

Second, more and more trade agreements have been linked with international labor standards in recent years. Some Chinese textile and apparel exporters have to face orders that contain labor standards. Their labor standards are higher than other companies and they have the ability to obtain relevant certifications. Therefore, raising labor standards does not have a great impact on these enterprises, and they can still guarantee a stable level of exports. In recent years, more and more export enterprises have obtained the labor standard certification in China, among which, the proportion of the garment industry reaches the maximum of $30.5 \%$, and the probability of blue textile trade barriers encountered by Chinese textile and garment enterprises is also decreasing. Therefore, the effect of raising the wage level on the export of our industry is less obvious.

Through the discussion in this article, the negative impact of international labor standards on China's export after the accession to the WTO actually exists. However, with the passage of time and the development of the export industry in China, the impact is now somewhat slowed down. Therefore, governments associations and enterprises should also look at international labor standards from different perspectives. While recognizing their negative impacts, they should also pay attention to their positive impacts so as to better cope with international labor standards.

\section{References}

[1] Aggarwal, Mita. Intemational Trade, Labor Standards, and Labor Market Conditions: An Evaluation of the Linkages[R].USITC, Working Paper.1995.

[2] Daniel A Zaheer, Breaking the Dead lock: Why and How Developing Countries should Accept Labor Standard in the WTO [J]. Stanford Journal of Law, business and Finance, vol.3, No.23, pp. 35-43

[3] Samira Bakhshi, William A.Kerr, Labour Standards as a Justification for Trade Barriers: Consumer Concerns, Protectionism and the Evidence [J]. The Estey Centre Journal of International Law and Trade Policy, vol11, pp. 89-93 